\title{
HISTOLOGICAL AND ENZYME HISTOCHEMICAL STUDIES ON THE TRANSITIONAL
}

\author{
GONADS OF GIANT GROUPER E. tauvina (PERCIFORMS: \\ SERRANIDAE) FROM THE
}

\author{
ARABIAN GULF COAST OF SAUDI ARABIA.
}

\author{
Nora Ahmed Obaid Al-kaabi \\ Dep. Of Biology, College of Science for Girls, Dammam University, \\ Dammam, Saudi Arabia
}

\begin{abstract}
The present work was carried out using twenty mature Epinephelus tauvina (Perciforms: Serranidae) collected from Arabian Gulf coast at Dammam City. Fishes of this species are known to undergo sex change during certain stage of their life cycle. Histological and enzyme histochemical studies were performed on gonads of the collected fishes. The examination of the gonads of E. tauvina revealed the presence of three developmental phases during the sex change process. These were: Female, early transition phase and late transition phase each one may subdivide into two stages. In female phase several developmental stages of the oocytes were recognized. At the beginning of early transition phase perinucleolar mature oocytes began degeneration while late transition phase characterized by rapid proliferation of spermatogenic cells. The histochemical studies demonstrated that alkaline phosphatase enzyme gave intense reaction in granulosa cells of mature oocytes while acid phosphatase gave an intense reaction in the interstitial cells and atretic follicles but $\Delta 5-3 \beta$ hydroxysteroid dehydrogenase enzyme gave intense reaction to special cells in capsule of gonads.
\end{abstract}

\section{Introduction:}

Tropical fishes show an exceptional range of reproductive strategies with regards to the expression of their sexuality (Devlin and Nagahama, 2002). Along with this diversity many different physiological regulations of gonadal sex differentiation or sex change have been demonstrated or suggested, including for instance the participation of the brain in a hermaphrodite's sex change (Grober and Sunobe, 1996; Black et al., 2004), and of external factors like temperature in species having Environmental Sex Determination (ESD) (Baroiller and D'Cotta, 2001). Despite this diversity of sex determination and sex differentiation processes, there is at least one well conserved factor common to nearly all teleost fish in the control of ovarian differentiation, which is the implication of estrogens and the enzyme needed for their synthesis. (Guiguen $\boldsymbol{e t}$ al., 2010).

Groupers are widely distributed throughout the tropical and subtropical waters of the world and are regarded as a favourite marine food fish. However, being protogynous hermaphrodites, groupers have been considered as study model for development and reproduction, especially for sex determination or sex differentiation, owing to the advantage that grouper gonad development undergoes transition from ovary to intersexual gonad and then to testis ( Shapiro, 1987; Zhou and Gui, 2008).

In such marine hermaphrodite fishes, sex changes are accomplished by complete alteration of gonadal anatomy and function as well as changes in behaviour (Tang $\boldsymbol{e t}$ al. 
1975; Reinboth, 1979 and Shapiro, 1987). It is still unknown when exactly, and what triggers their sex change from female to functional males. In contrast to numerous studies on reproductive cycles of protogynous hermaphrodite fishes (Cardwell and Liley, 1991; Johnson et al. 1998; Lee et al., 2002; Mackie, 2006 and Liu \&de Mitcheson, 2009), very few studies have pointed out the endocrine changes in fish that undergo female to male sex changes (Tan and Tan, 1974; Chen et al. 1980; Reinboth, 1979\& 1988; Nakamura et al. 1989; Siau, 1994 and Kobayashi et al., 2010).

The different stages of oocyte maturation as well as the existence of protogny in E. tauvina were previously reported by Abu Hakima (1987). The present study aims to give some details on histological and histochemical changes on gonads during its sex change process.

\section{Material and Methods:}

Twenty sexually mature E. tauvina fishes were collected from the coast of Arabian Gulf at Dammam City. (The collected fishes ranged in total length between 30.5 and $95 \mathrm{~cm}$ and in weight between 345 and 14500 grams). The specimens were collected over one year period. For the identification of developmental stages and different phases, fresh gonads were fixed in $10 \%$ neutral formalin sectioned at $5 \mu \mathrm{m}$ thick and stained with haematoxylin and Eosin (Bancroft and Gamble, 2008).

For histochemical studies the frozen unfixed sections of gonads were cut on cryostat at $-10{ }^{\circ} \mathrm{C}$ at $10 \mu \mathrm{m}$ thickness for studying enzymes (acid phosphatase enzyme by the Gomori lead method ( Bitensky , 1963 ) and alkaline phosphatase enzyme by direct lead method ( El-Aser and Hassanein , 1975) and $\Delta 5-3 \beta$ hydroxysteroid dehydrogenase ( modified by Nagahama et al.,1976 ).

\section{Result:}

The gonads of E. tauvina are divided into two lobes located on either side of the intestine attached to the peritoneal wall. On basis of histological changes, entire process of sex changes was assigned into three developmental phases: female, early transition and late transition phase. Each phase may sub-divide into two stages early and late.

In the female phase the ovarian tissue contains small oocytes in early development stage, it was arranged in lamellae, which extended into ventral, membrane bound ovarian cavity or lumen and also the presence of atretic follicles, Fig. (1).

The last phase characterized by presence of numerous yolk globules (circular in shape and acidophilic) inbetween yolk vesicles. The nucleus increase in size with irregular contours. The oocyte surrounded by acidophilic zona radiata and granulosa and thecal cells, Fig. (2). During the same stage several oocytes appear at perinucleolar stage in which the oocyte increased in size with large nucleus contain many nucleoli arranged in the inner contour of the nucleus and the yolk globules varies in density of eosinophelic yolk from light to dark, Fig. (3).

Several individual of gonads of $E$. tauvina shows early transition phase shows many small oocytes with large nucleus contain 1-3 nucleolus surrounded by dark basophilic cytoplasm all these at chromatin nucleolus stage, Fig. (4). The last phase characterized by degeneration of primary oocytes and simultaneous spermatogonal proliferation in the germinal epithelium lining ovarian lumen.

At the late phase of transition also appears few semineferous cysts contain spermatocytes and spermatids which appears in the interstitial connective tissue in between oocytes in the early stage, Fig. (5).

The gonads in the later stage surrounded by thick capsule consisting of numerous connective tissue fibers enclosing in between steroidogenic cells containing centrally located nucleoli, Fig. (6). 
The histochemical examination of $E$. tauvina gonads revealed that in female stage the ovary surrounded by capsule containing cells aggregates, which gave moderate reaction to alkaline phosphatase enzyme. In addition, the ovary of $E$. tauvina filled with numerous oocyte which show an intense reaction to alkaline phosphatase in granulosa cells while the cytoplasm of oocyte gave reaction varies from week to moderate to same enzyme, Fig.(7).

By magnification of the later stages showed an intense reaction in granulosa cells while zona radiata gave no reaction to some enzyme. Few atretic follicles gave also an intense reaction to alkaline phosphatase enzyme, also the cytoplasm around the nucleus before its disappearance gave an intense reaction to the same enzyme, Fig. (8).

In early stages of transmission the gonads filled with mature oocytes which more crowded and gave an intense reaction of alkaline phosphatase in the outer contours of oocytes, Fig. (9). Also, few atretic follicles appeared with aggregation of interstitial spermatogenic cells in- between mature oocytes and the both gave an intense reaction to alkaline phosphatase, and there were some clusters of cells in capsule gave an intense reaction to alkaline phosphatase, Fig. (10).

Concerning the reaction of acid phosphatase in the ovary of E. tauvina, it was noticed that the intense reaction of this enzyme were concerned to connective tissue in between mature oocyte while the granulosa cells which surround the oocyte gave moderate reaction, Fig. (11). The gonads in early stages of transition in addition to interstitial connective tissue there were aggregation of testicular tissue both gave moderate to intense reaction to acid phosphatase, Fig (12).

The study of $\Delta 5-3 \beta$ hydroxy steroid dehydrogenase reaction in the ovary of $E$. tauvina showed intense reaction in some granulosa cells around mature oocytes, Fig.(13), while in gonads in early stages of transition also appeared groups of cells in connective tissue capsule which gave an intense reaction, Fig.(14). Meanwhile, in many situations some aggregation of interstitial connective tissue cells gave moderate reaction to the same enzyme.

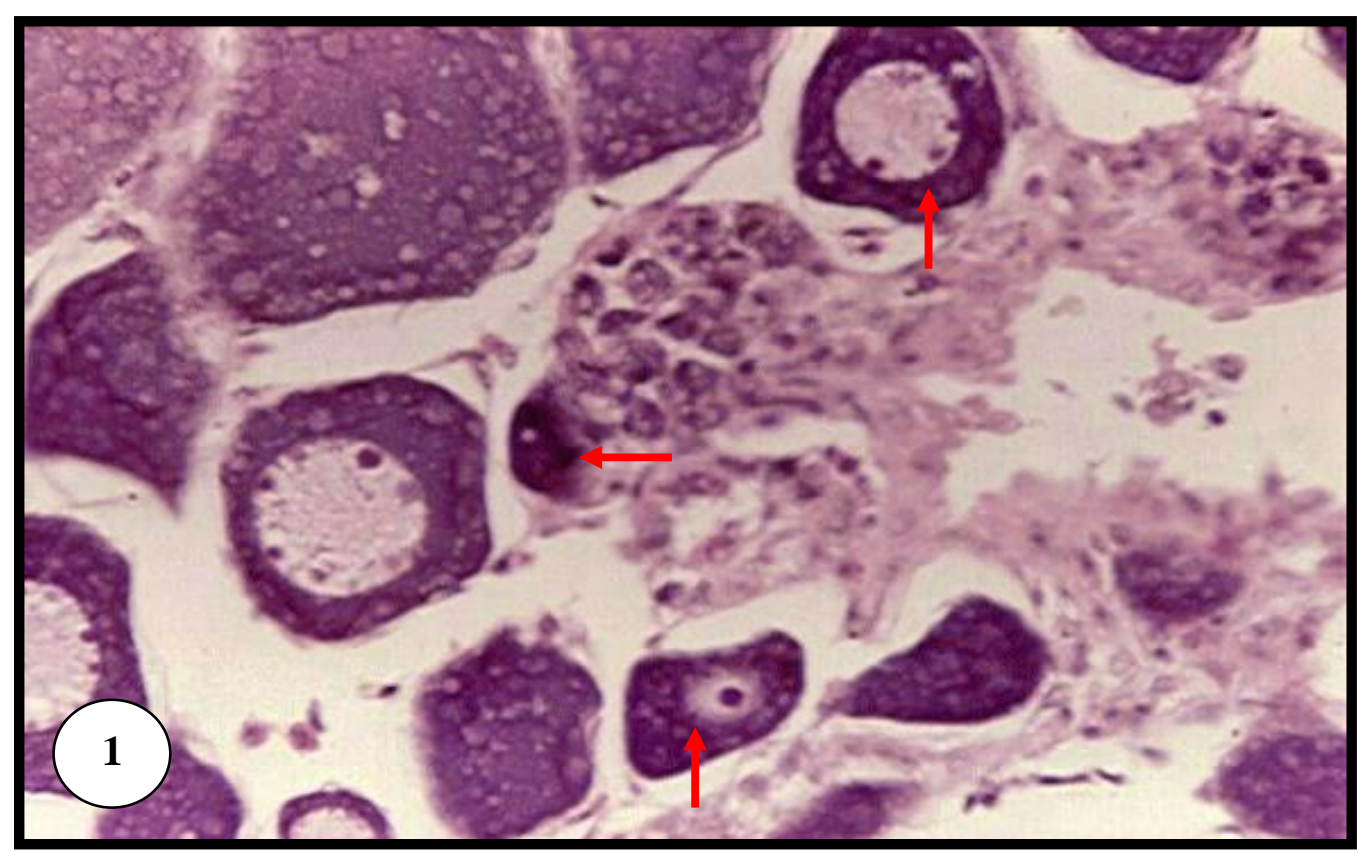

Fig. (1): Light micrograph of gonad of E.tauvina fish showing the ovarian tissues contains oocytes in early stage were arranged into lamellae and presence of atretic follicle (arrow). H\&E stain (4 $\times 10)$. 
Nora Ahmed

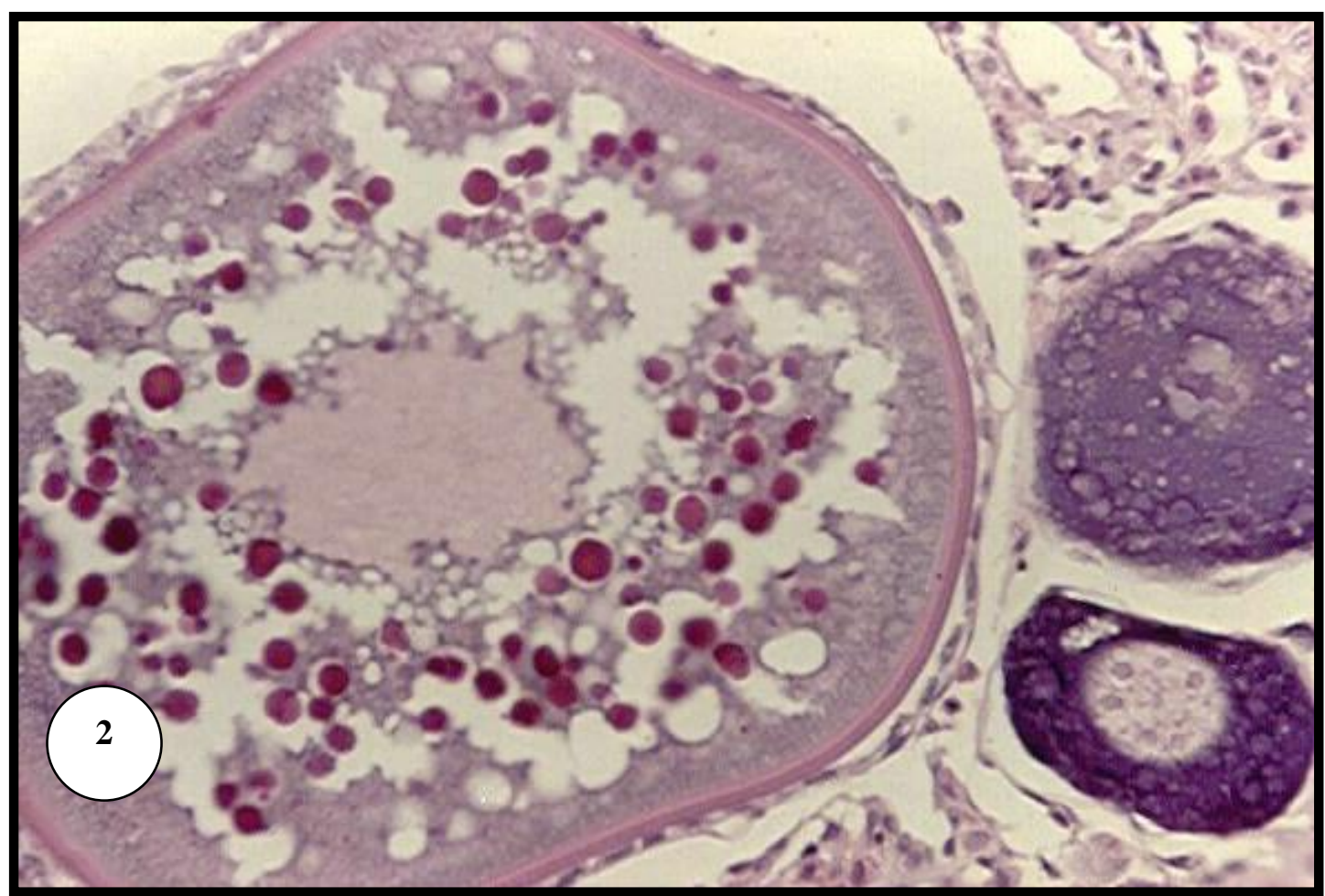

Fig (2): Light micrograph of gonad of E.tauvina fish showing female phase characterized by presence of circular acidophilic yolk globules (arrow). $H \& E$ stain $(40 \times 10)$.

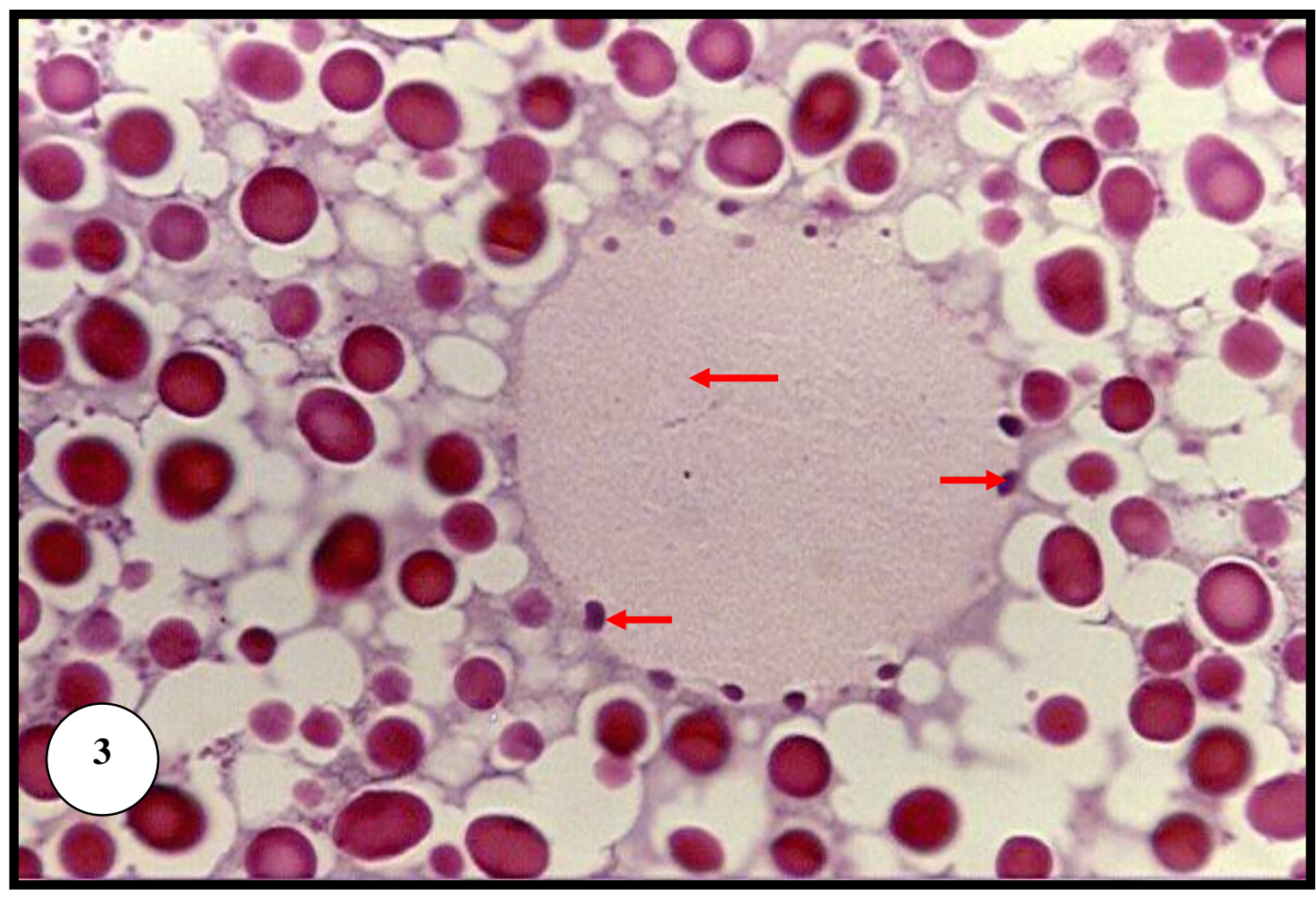

Fig. (3): Light micrograph of gonad of E. tauvina fish showing: perinucleolar stage showing numerous nucleoli arranged in the inner contour of nucleus (arrows). H\&E stain, $(40 \times 10)$. 


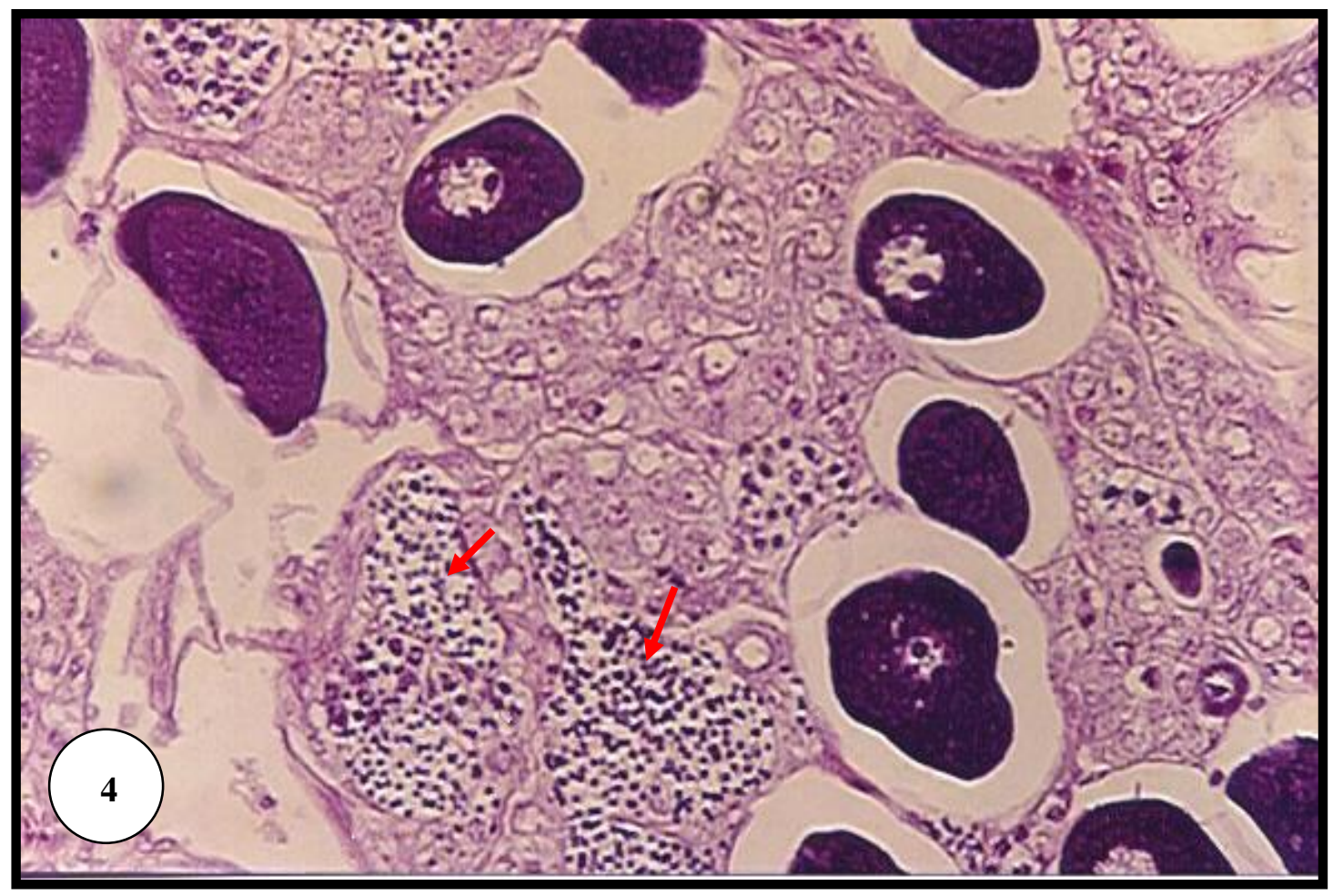

Fig.(4): light micrograph of gonad of E. tauvina fish showing : early transition phase showing degeneration of primary oocytes and appearance of testicular tissue (arrows). H\&E stain (40 × 10).

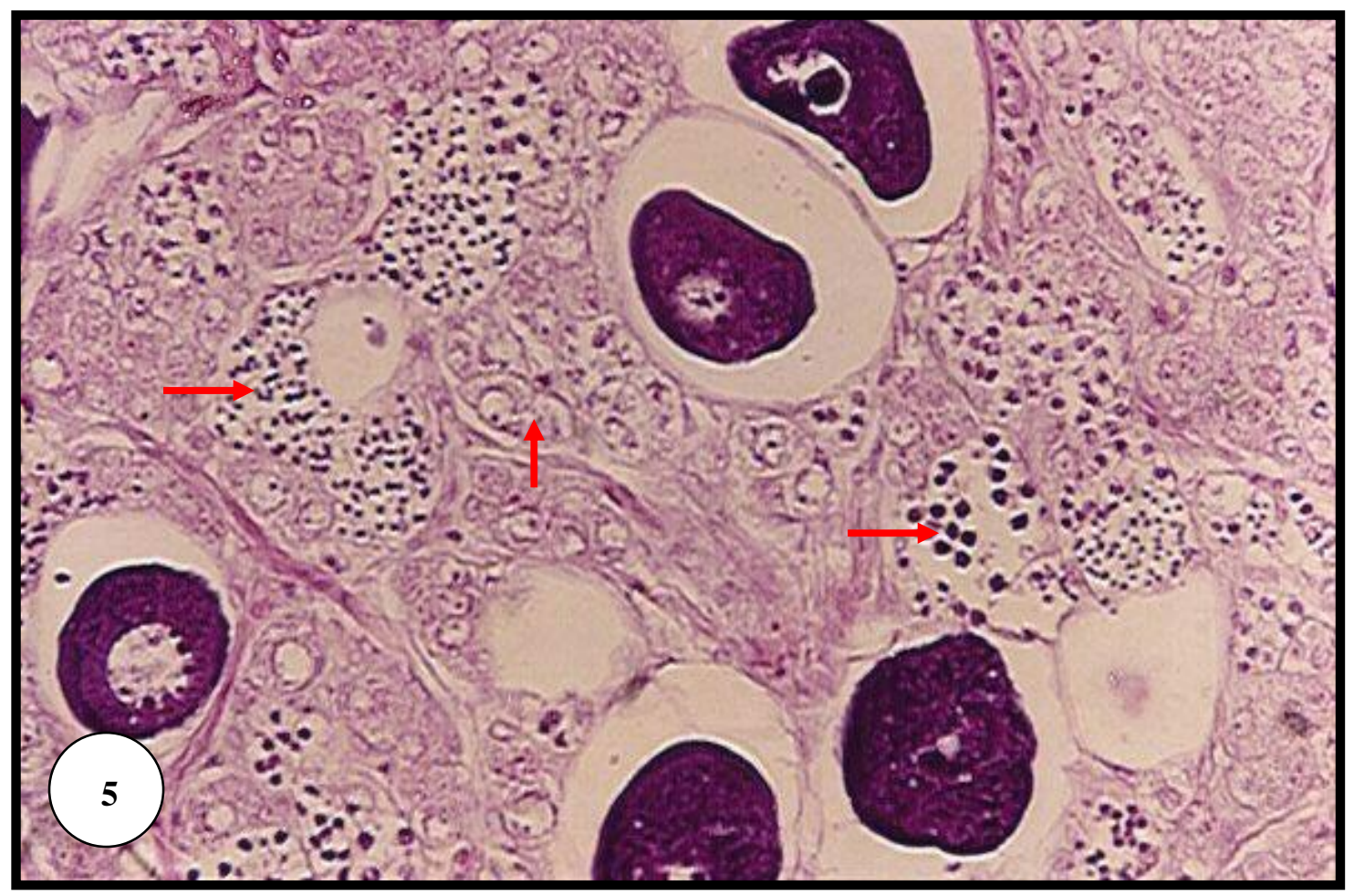

Fig. (5): light micrograph of gonad of E. tauvina fish showing: oocytes in early stages and increase number of cysts which filled with different stages of spermatogenesis from spermatogonia to spermatids (arrows). $H \& E$ stain $(40 \times 10)$. 


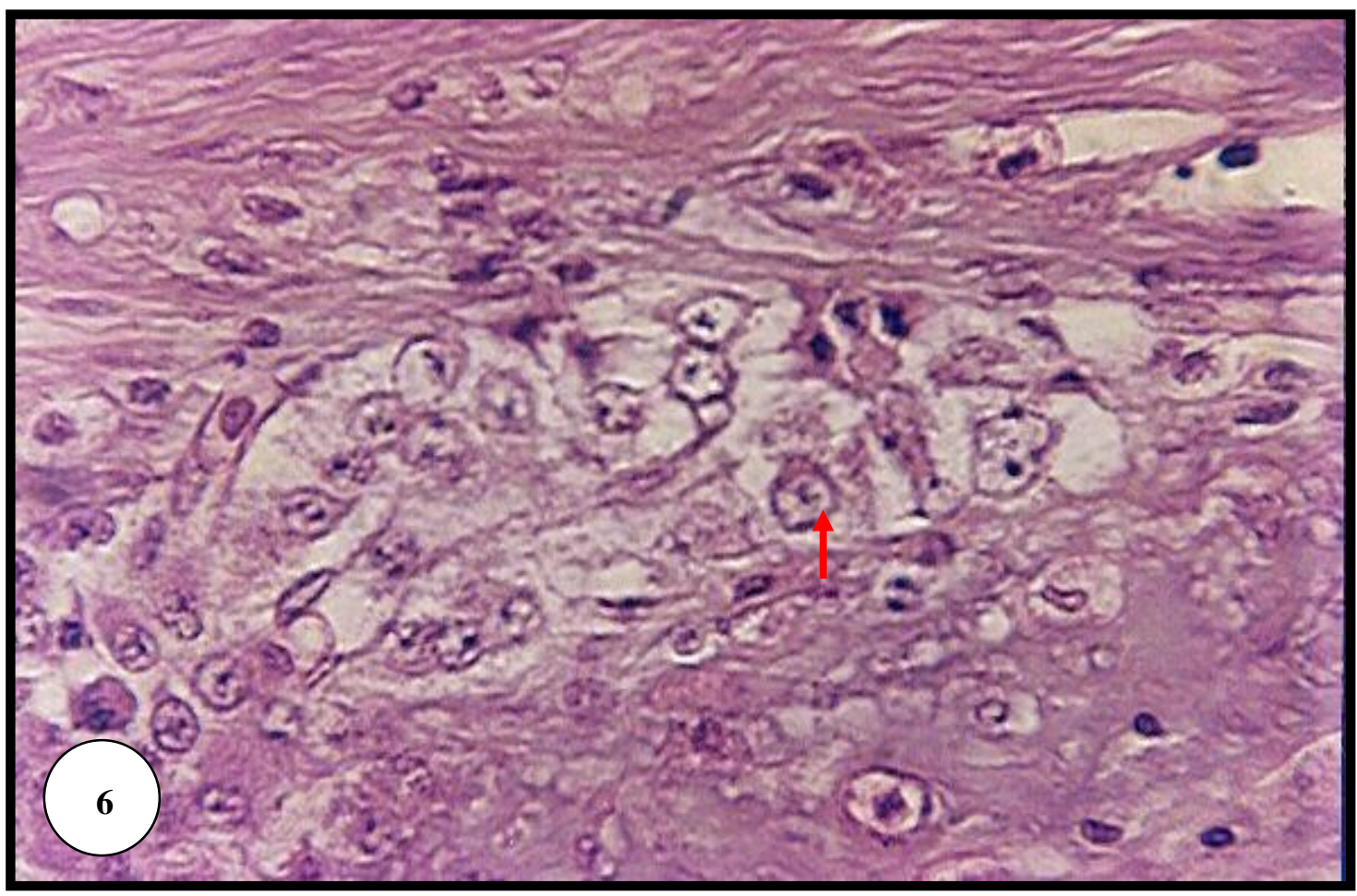

Fig. (6): light micrograph of gonad of E. tauvina fish showing: capsules consist of connective tissue fibers enclosing aggregations of steroidogenic cells highly vacuolated with centrally located nuclei. (arrow). H\&E stain $(10 \times 100)$.

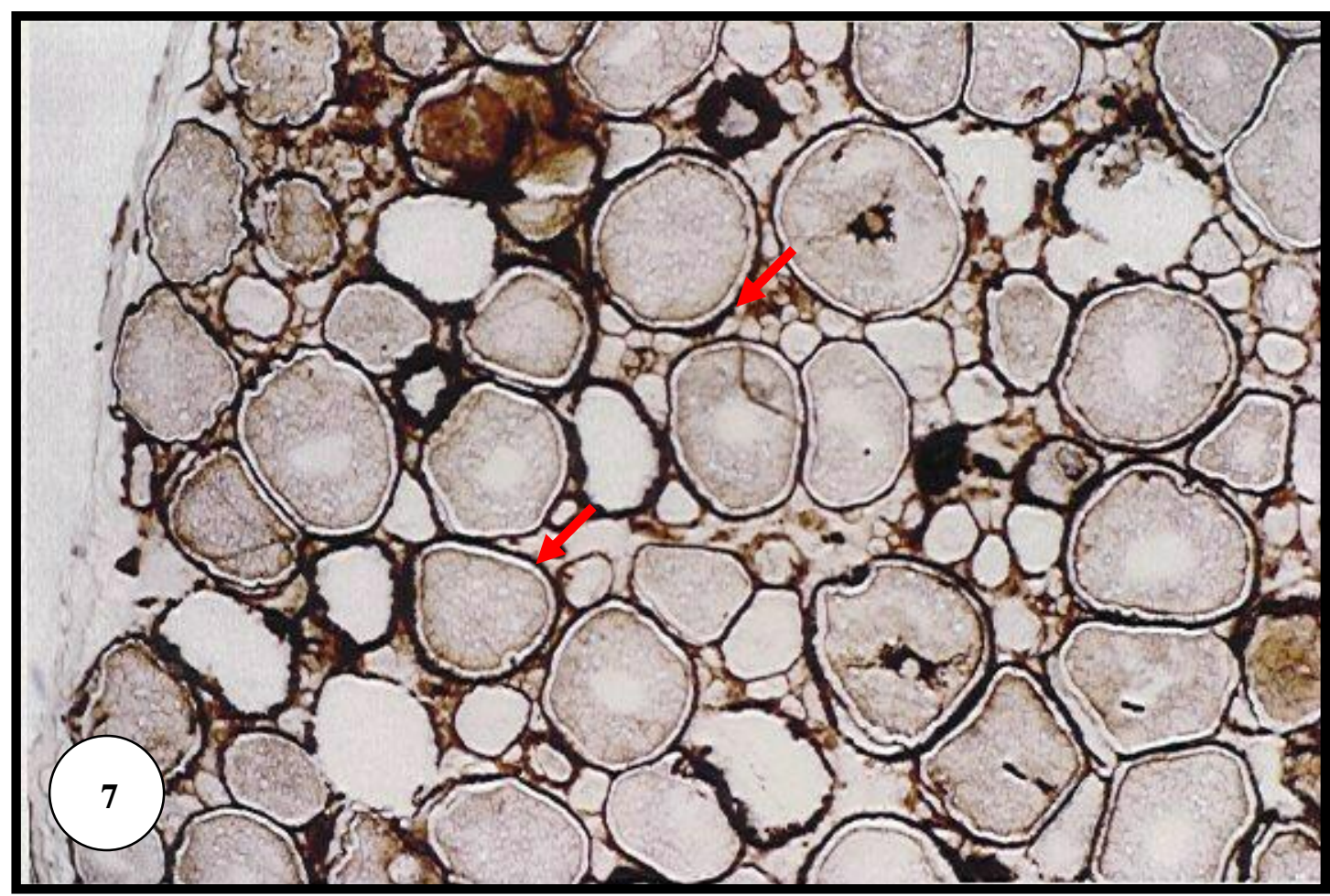

Fig. (7): light micrograph of gonad of E. tauvina fish showing: an intense reaction of alkaline phosphatase appeared in granulosa cells which surrounded the mature oocyte (arrows), moderate reaction of same enzyme in cytoplasm of oocyte. Gomori reaction $(10 \times 4)$. 


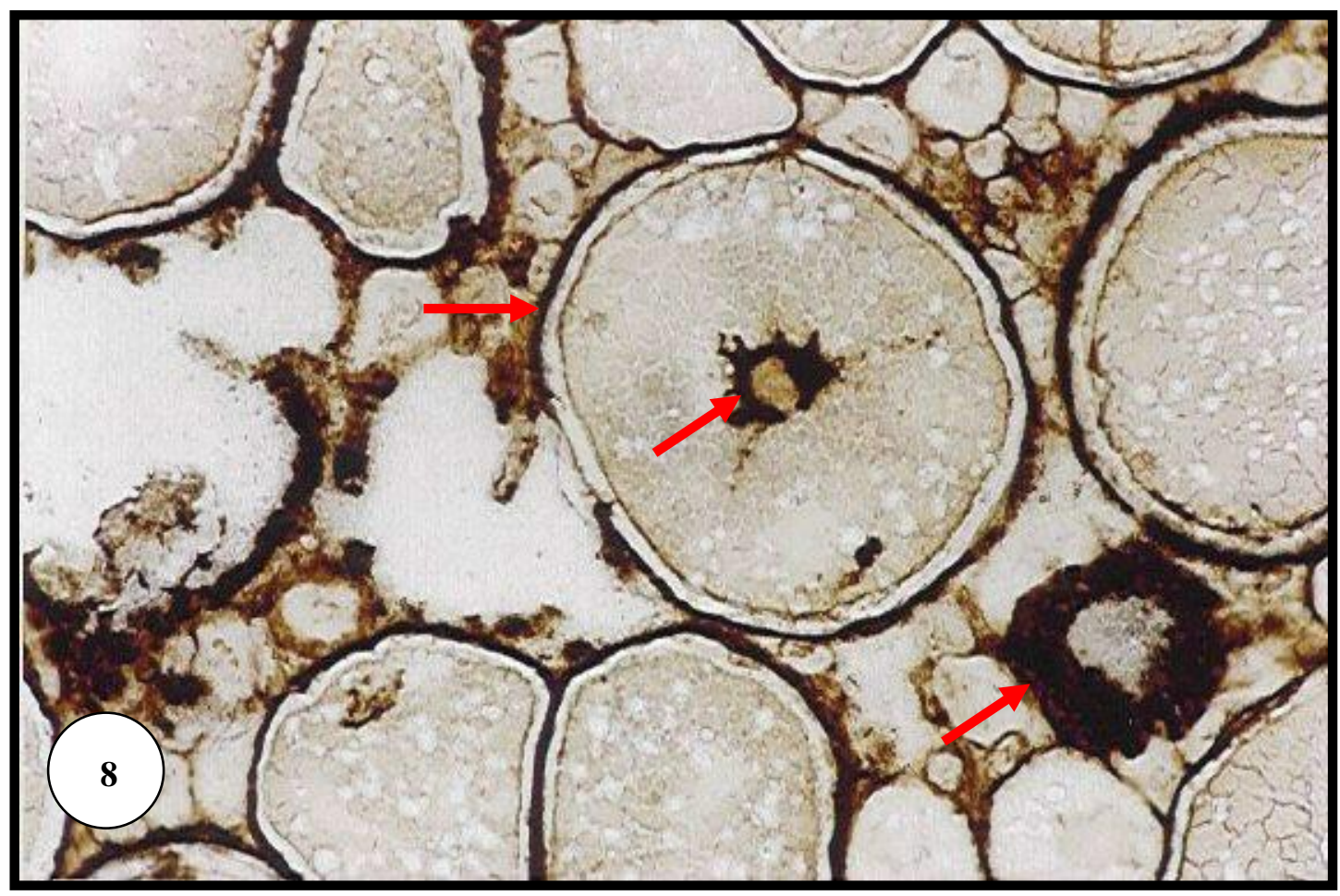

Fig. (8): light micrograph of gonad of E. tauvina fish showing: an intense reaction around mature oocyte and around the wall of atretic follicle, also in yolk around nucleus of mature oocyte (arrows). Gomori reaction $(10 \times 10)$.

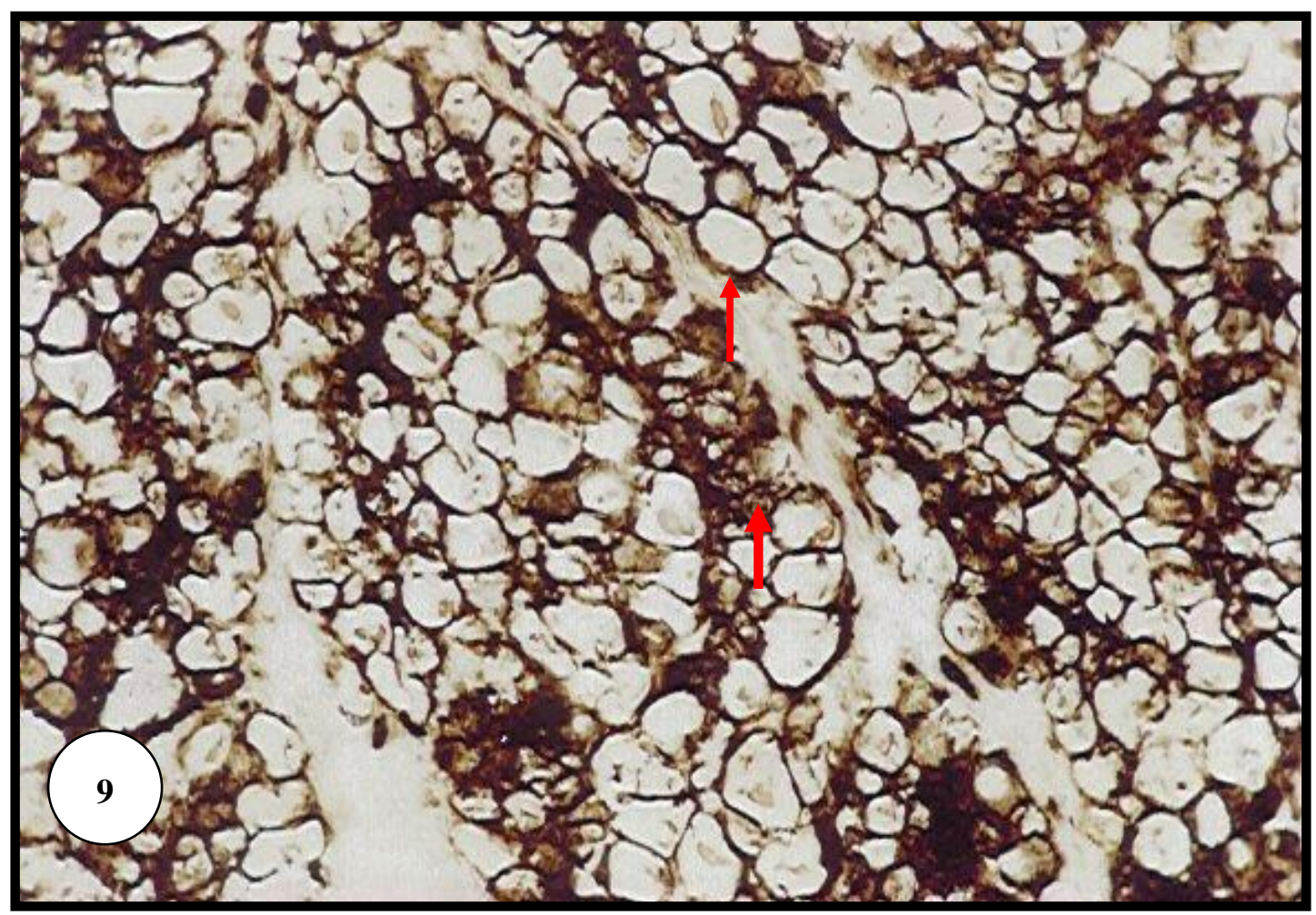

Fig. (9): light micrograph of gonad of E. tauvina fish showing: mature stages shows numerous mature oocytes counter membrane and some atretic follicles and few interstitial spermatogenic cells reacted positively with alkaline phosphatase (arrows), and negative reaction in cytoplasm of mature oocytes .

Gomori reaction $(10 \times 10)$. 


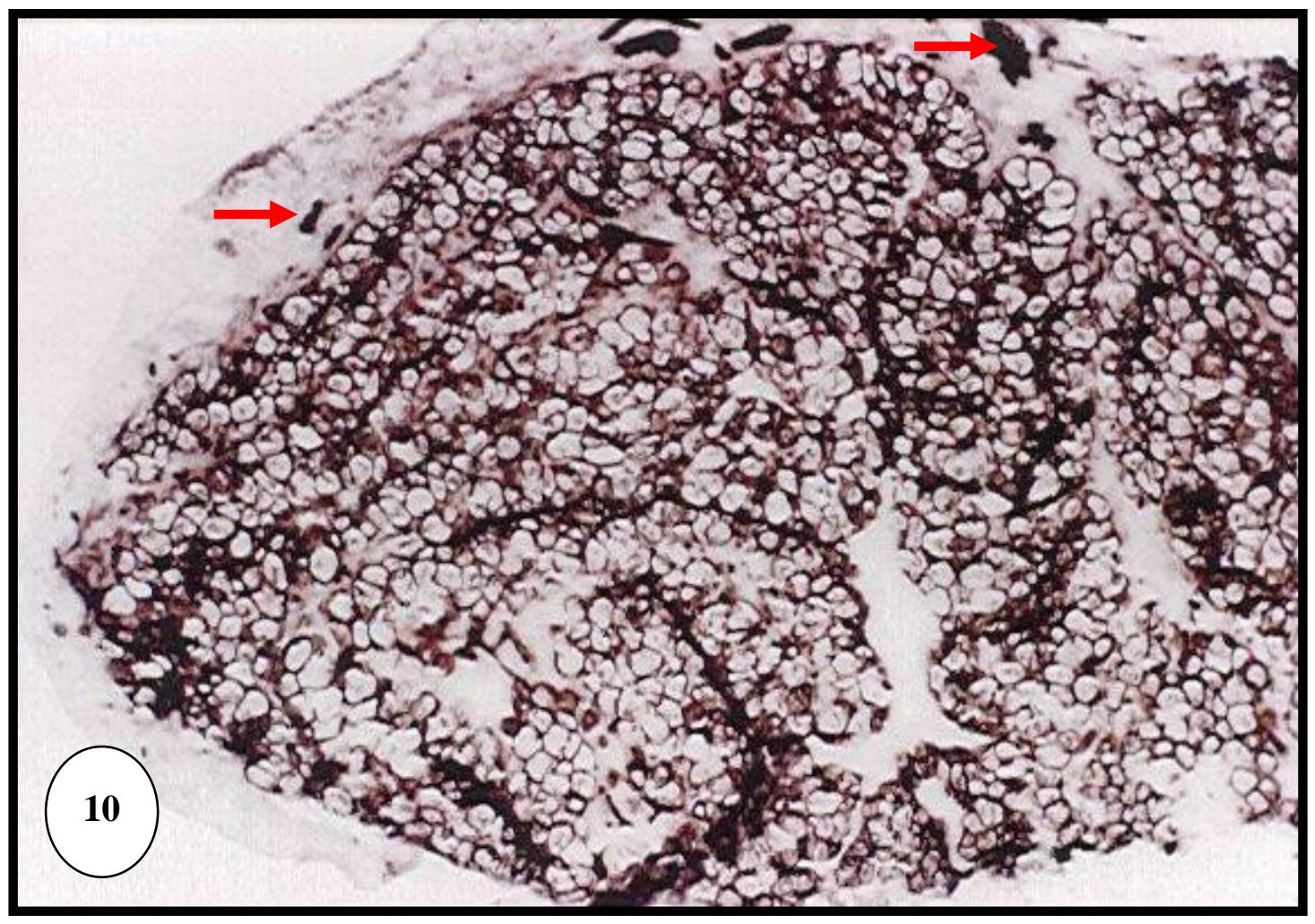

Fig. (10): light micrograph of gonad of E. tauvina fish showing: an intense reaction as mentioned in Fig. (9) In addition to some aggregation of steroidogenic cells in the capsule gave an intense reaction to alkaline phosphatase (arrows). Gomori reaction (10×4).

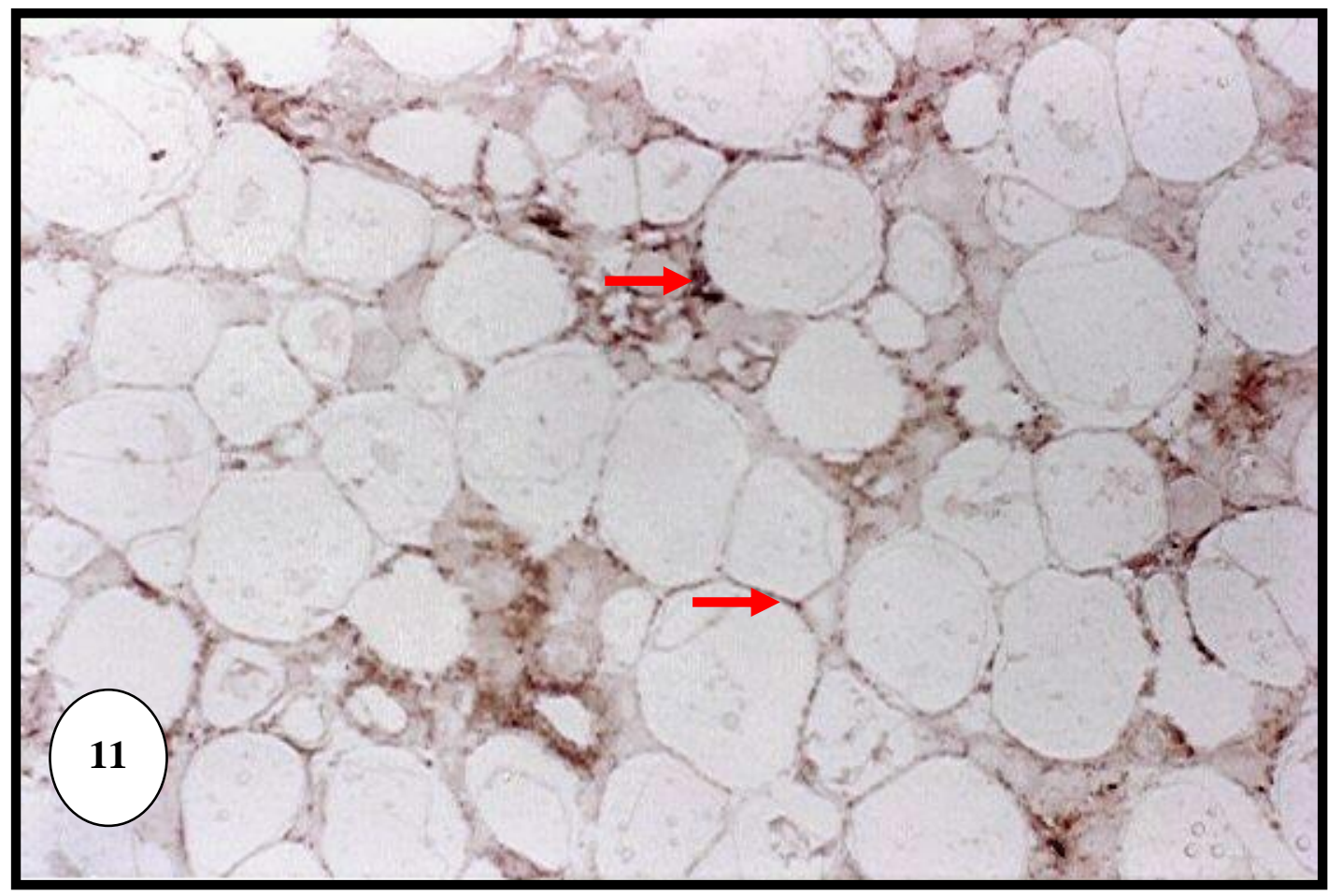

Fig. (11): light micrograph of gonad of E. tauvina fish showing: an intense reaction of acid phosphatase in the connective tissue in-between mature oocytes and moderate reaction in granulosa cells surrounded mature oocytes. Gomori reaction $(10 \times 4)$. 



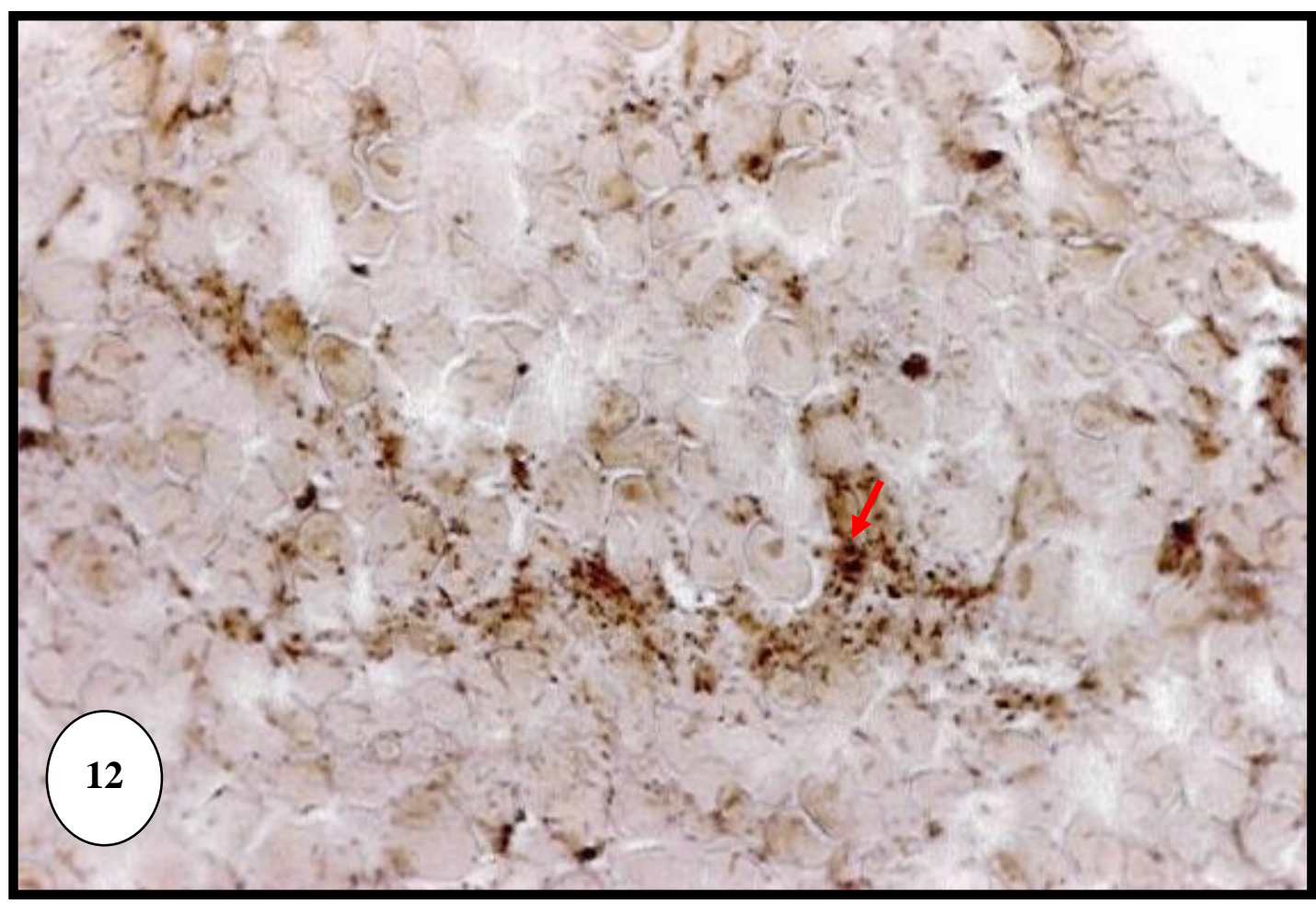

Fig. (12): light micrograph of gonad of E. tauvina fish showing: an interstitial connective tissue and aggregations of testicular tissues gave reaction to acid phosphatase varies from moderate to intense reaction (arrows). . Gomori reaction $(10 \times 10)$.

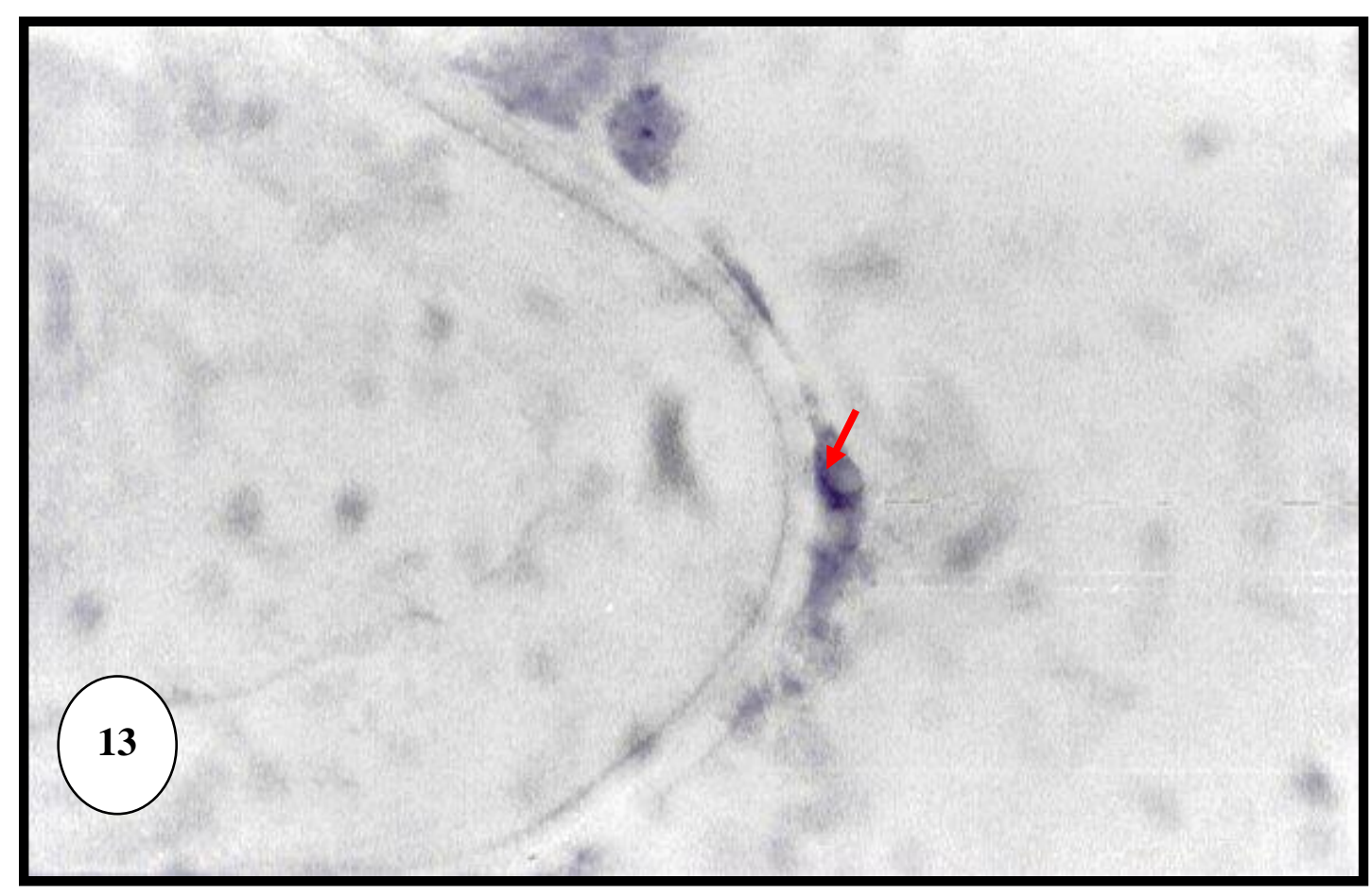

Fig. (13): light micrograph of gonad of E. tauvina fish showing: intense reaction of enzyme $\Delta 5-3 \beta H S D$ in some granulosa cells around mature oocytes. $(10 \times 100)$. 


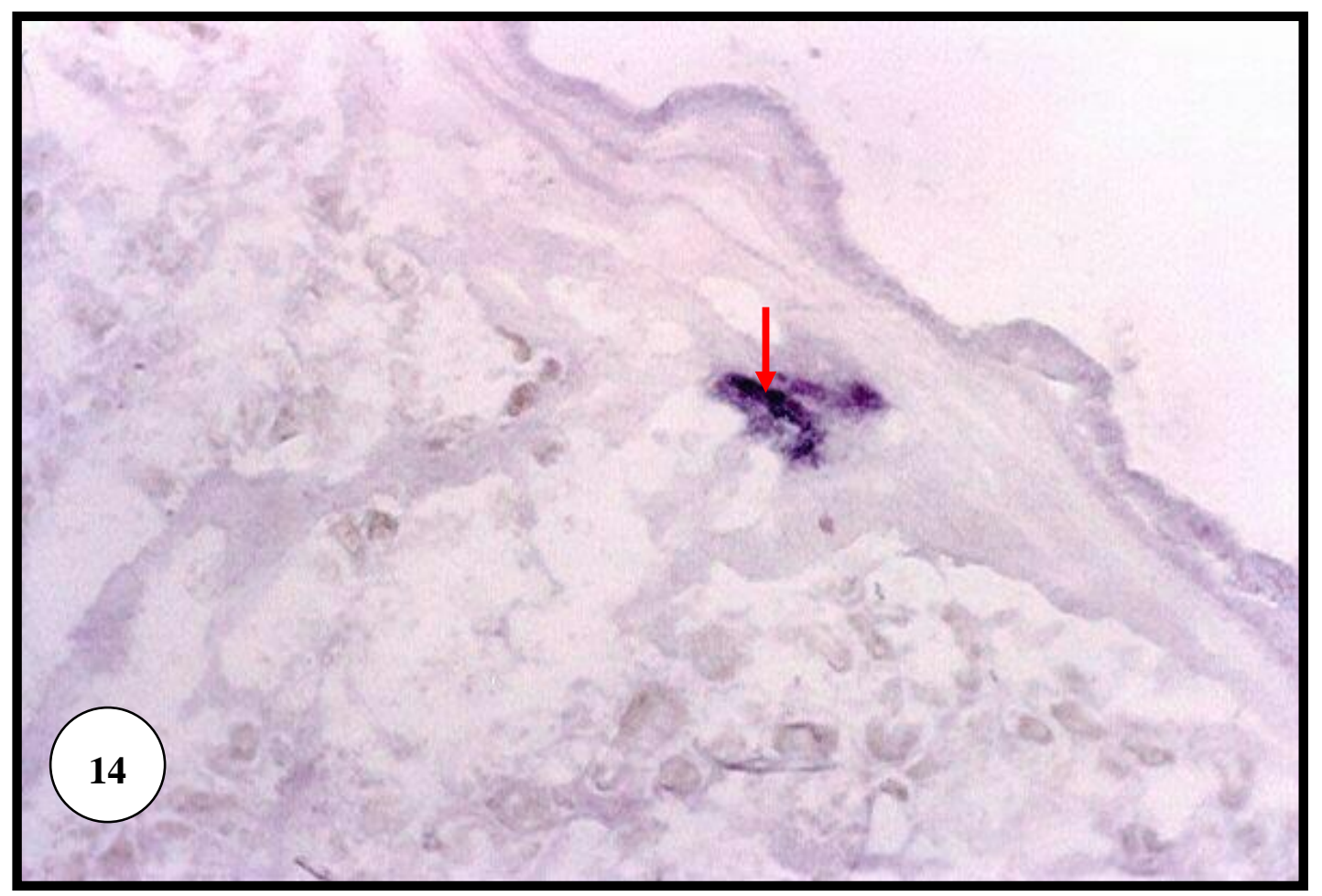

Fig. (14): light micrograph of gonad of E. tauvina fish showing: some aggregations of cells in capsule gave an intense reaction to $\triangle 5-3 \beta H S D$ enzyme. $(10 \times 10)$.

\section{Discussion:}

The groupers are wide spread in both tropical and temperate seas are commonly heavily fished. The brown spotted grouper, Epinephelus tauvina, is one of the most important food fishes in Saudi Arabia and in Kuwait, (Abu-Hakima, 1987). In our findings we classify the gonads of $E$. tauvina into three stages: female, early transition and late transition phase, which also subdivided into two stages. This most probably included in the seven stages recognized by Abu- Hakima (1987).

The E. tauvina shows protogynous hermaphroditism in accordance with (Bhandari et al., 2003) our findings in $E$. tauvina not of that the oocytes showed several developmental stages which arranged into lamellae in accordance with (Bouain and Siau, 1983). There were several changes occurs during ripening of oocytes which easily recognized by presence of yolk in the ooplasm (Macer, 1974).

The present results revealed that at the beginning of early transition stage both perinuclear and mature oocyte appeared and accompanied with few spermatogenic cells in accordance with (Bhandari et al.,2003 ) who added that there were clear proliferation of spermatogonia towards the centre of lamellae.

In late transition phase stage we notice further degeneration of oocyte and rapid proliferation in addition to active spermatogenesis in accordance with (Abbasi et al., 2007) who described the transitional gonads of the protogynous Epinephelus coioides were characterized by the concurrent degeneration of all oocytes and the proliferation of spermatocysts.

Foci of atresia and atretic bodies were routinely observed in histological sections of the gonads at different stages in E. tauvina. Atresia in the gonads of protogynous hermaphrodites is well documented by Smith (1965). In the present study, atretic follicles were most evident in the transforming gonads. Hastings (1981) has described three modes of resorption of ovarian tissue in the transforming gonads of Hemanthias vivanus. These include fragmentation of pre-vitellogenic oocytes, phagocytosis of 
vitellogenic oocytes and invasion and breakdown of mature, unovulated eggs. In the present study, all three modes of breakdown were noted in the transforming gonads of E. tauvina. The invasion and breakdown of the mature eggs is similar to pattern typically associated with resorption of unshed eggs (Saidapur, 1978).

In an attempt to find a role between enzymatic activity and transition of female to male membrane in gonads of E. tauvina. Our result revealed an intense reaction to alkaline phosphatase in granulosa cells and atretic follicles indicating its importance in synthesis of yolk during maturation.

The present results showed moderate to intensive reaction of acid phosphatase in the granulosa cells which surround the oocytes and in connective tissue in between mature oocytes, also the same result was observed in the interstitial connective tissue and the aggregation of testicular tissue in the gonads of E. tauvina at the early transitional stage, which revealed the effective role of these cells in digestion and removing the yolk and cellular components of the oocytes in the ovary preparing it to the next stage ( Saidapur,1978 and Alkaabi \& Salim, 2002).

Concerning $\quad \Delta 5-3 \beta$ hydroxysteroid dehydrogenase our result revealed that some granulosa cells around mature oocytes gave intense positive reaction while the gonads in transition stage some cells in capsule in addition to some interstitial connective tissue cells distributed all over the gonads gave positive reaction to same enzyme in accordance with (Fedorov $\boldsymbol{e t}$ al. 1990 and Alkaabi \& Salim,2002), also with (Alam et al., 2005) who have observed clusters of strongly immunopositive cells in tissue near blood vessels in the tunica ovary surrounding the outer periphery in protogynous grouper Epinephelus merra these cells possibly play a physiological role in oocyte growth and gonadal restructuring during the sex change of individuals of this species, in contrast immunopositive cells were localized in the theca layer surrounding the outer periphery of oocytes.

\section{References:}

Abbasi F, Shahrbanou $O$ and Matinfar A (2007): Reversal sex change in the protogynous fish

Epinephelus coioides in the Persian Gulf water. Iranian J. Biol.20 (1):121-127.

Abu-Hakima R (1987): Aspects of the reproductive biology of the grouper, Epinephelus tauvina (Forscal), in Kuwaiti waters. J. fish biol., 30:213-222.

Alam M A, Komuro H, Bhandari R K, Nakamura $S$, Soyano $K$ and Nakamura $M$ (2005): Immunohistochemical evidence identifying the site of androgen production in the ovary of the protogynous grouper Epinephelus merra. Cell Tissue Res., 320(2):323-329.

Al-Kaabi N A and Salem H F (2002): Histological and histochemical studies on gonads of grouper fish (Epinephelus chlorostigma) in Arabian Gulf. Egypt.J.Appl. Sci., 17(11):53-70.

Bancroft J D and Gamble $M$ (2008): Theory and Practice of Histological Techniques. $6^{\text {th }}$ ed. Churchill Livingstone. Elsevier.

Baroiller J F, D'Cotta H (2001): Environment and sex determination in farmed fish. Comp.Biochem. Physiol. C 130, 399-409.

Bhandari R K, Komuro H, Nakamura S, Higa $M$ and Nakamura M (2003): Gonadal restructuring and correlative steroid hormone profiles during natural sex changes in protogynous honeycomb grouper (Epinephelus merra). Zool. Sci., 20(11): 1399-1404.

Bitensky L (1963): Modification to the Gomori acid phosphatase technique for controlled temperature frozen sections. Quart. J. Micros. Sci., 104:193-196.

Black M P, Reavis R H and Grober M S (2004): Socially induced sex change regulates forebrain isotocin in Lythrypnus dalli. Neuroreport 15, 185-189.

Bouain A and Siau Y (1983): Observations on the female reproductive cycle and fecundity of three species of groupers (Epinephelus) from 
the southeast Tunisian seashore. Marine Biology, 73:211-220.

CardwelJ Tand Liley N R (1991): Hormonal control of sex and colour change in the parrotfish, Sparisoma viride. Gen. Comp. Endocrinol., 81: 7-20.

Chen C P, Hsieh H L, Chang K H (1980): Some aspects of the sex change and reproductive biology of the grouper, Epinephelus diacanthus (Cuvier ET valenciensis). Bull. Inst. Zool. Academia Sinica, 19: 11-17.

Devlin R H and Nagahama Y (2002): Sex determination and sex differentiation in fish: an overview of genetic, physiological, and environmental influences. Aquaculture 208, 191-364.

El-Aaser A A and Hassanein S H M (1975): A new direct lead technique for histochemical demonstration of alkaline phosphatase activity. Act. Biol. Acad. Sci. Hung., 26(1-2):105-110.

Fedorov K Y, Zubova S E, Semenov V V and Burlakov A B (1990): Secretory cells gonads of juvenile starlet sturgeon, Acipenser ruthenus, during sexual differentiation. J. Icthyol., 30(3):1-13.

Grober M S, Sunobe T (1996): Serial adult sex change involves rapid and reversible changes in forebrain neurochemistry. Neuroreport 7, 2945-2949.

Guiguen Y, Fostier A, Piferrer F and Chang C F (2010): Ovarian aromatase and estrogens: A pivotal role for gonadal sex differentiation and sex change in fish, General and Comparative Endocrinology 165: 352-366.

Hastings P A (1981): Gonad morphology and the protogynous hermaphrodite Hemanthias vivanus ( Jordan and Swain ). J.Fish Biol., 18: 443-454.

Johnson $\mathbf{K}$ A, Thomas $\mathbf{P}$ and Wilson $\mathbf{R}$ (1998): Seasonal cycles of gonadal development and plasma sex steroid levels in Epinephelus morio, a protogynous grouper in the eastern Gulf of Mexico, J. Fish Biol., 52:502-518.

Kobayashi Y, Alam M A, Horiguchi R, Shimizu A and Nakamura M (2010): Sexually dimorphic expression of gonadotropin subunits in the pituitary of protogynous honeycomb grouper (Epinephelus merra): Evidence that follicle-stimulating hormone (FSH) induces gonadal sex change. BOR papers in press published on February 10, 2010 as DOI: 10.1095/ biolreprod.109.080986

Lee Y D, Park S H, Takemura A and Takano K (2002): Histological observations of seasonal reproductive and lunar- related spawning cycle in the female honeycomb grouper, Epinephelus merra in Okinawa waters. Fish Sci., 68:872877.

Liu M and de Mitcheson Y S (2009): Gonad development during sexual differentiation in hatchery-produced orange-spotted grouper (Epinephelus coioides) and humpback grouper (Cromileptes altivelis) (Pisces: Serranidae, Epinephelinae). Aquaculture, 287(1-2): 191202.

Macer C T (1974): The reproductive biology of the horse mackerel Trachurus trachurus (L) in the North sea and English Channel., J. Fish Biol., 6:415-438.

Mackie M C (2006): Anatomical changes to the gonad during protogynous sex change in the half-moon grouper Epinephelus rivulatus (Valenciennes). J.Fish Biol.69 (1): 176-186.

Nagahama Y, Chan K and Hoar W S (1976): Histochemistry and ultrastructure of pre- and post-ovulatory follicles in the ovary of the goldfish. Carassius auratus. Can. J. Zool., 54:1128-1139.

Nakamura M, Hourigan T F, Yamauchi K, Nagahama $Y$ and Grau G E (1989): Histological and ultrastructural evidence for the role of gonadal steroid hormones in sex change in the protogynous wrase thalassoma dupery. Env. Biol. Fish, 24:117-136.

Reinboth R (1979): On steroidogenic pathways in ambisexual fishes.Proc. Indian Nat. Sci. Acad., 45B: 421-428.

Reinboth R (1988): Physiological problems of teleost amphisexuality. Environ.Biol.Fish, 22:249-259.

Saidapur S K (1978): Follicular atresia in the ovaries of nonmammalian vertebrates. Int. Rev.Cytol., 54:225-244.

Shapiro D Y (1987): Differentiation and evolution of sex change in fishes. Bioscience, 37: 490-497. 


\section{Nora Ahmed}

Siau Y (1994): Population structure, reproduction and sex-change in a tropical east Atlantic grouper. J.Fish Biol., 44: 205-211.

Smith C L (1965): The patterns of sexuality and the classification of serranid fishes. Am. Museum Novitates, 2207: 1-20.

Tan S M and Tan K S (1974): Biology of the tropical grouper, Epinephelus tauvina (Forskal).1.A preliminary study on hermaphroditism in E. tauvina. Sing J. Pri. Ind., 2: 123-133.
Tang F, Chan S T H and Lofts B (1975): A study on the $3 \beta$ and $17 \beta$ - hydroxysteroid dehydrogenase activities in the gonads of monopterus albus at various sexual phases during natural sex reversal. J. Zool., 175: 571580 .

Zhou L and Gui J F (2008): Molecular mechanisms underlying sex change in hermaphroditic groupers, Fish Physiology and Biochemistry, 15:75-79. 
دراسات نسيجيه وكيميانسيجيه إنزيمية على المناسل المتحولة للهامور العملاق Epinephelus tauvina

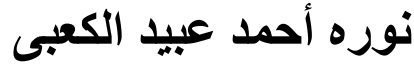 \\ قسم الأحياء ، كلية العلوم للبنات ، جامعلة الكعاد الدمام

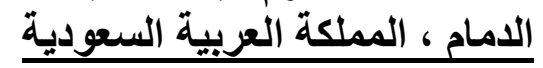

تمت الدر اسة على مناسل أسماك الهامور العملاق Epinephelus tauvina بعدد 20 سمكة تم المات

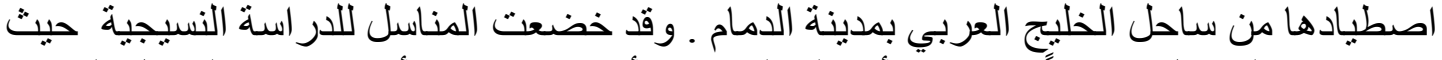

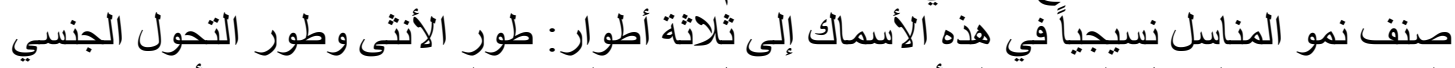

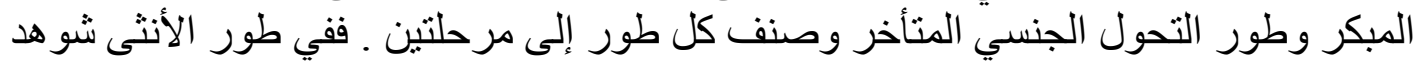

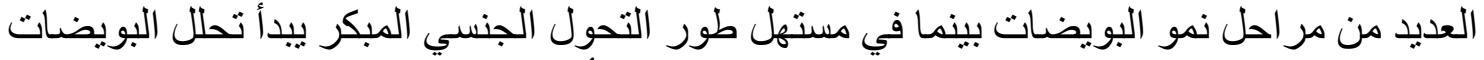

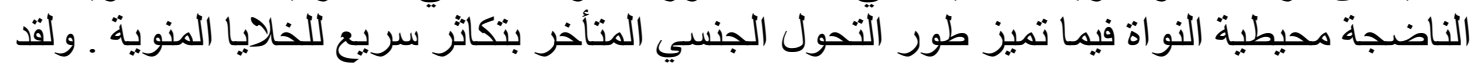

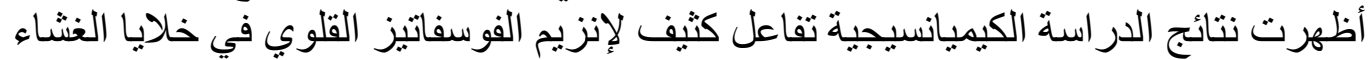

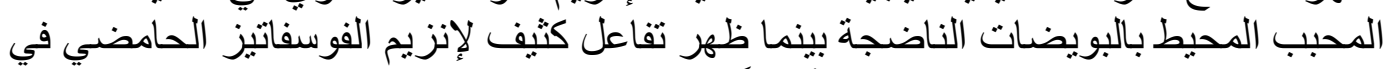

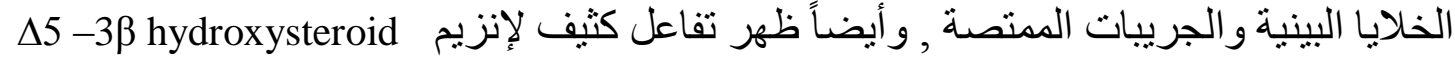
dehydrogenase 